УДК 94(420):327.061

\title{
Андрій Грубінко
}

д-р. іст. наук, доц.

Тернопільський національний економічний університет

46000, Україна, Тернопіль, вул. Львівська, 11

E-mail: gav_tnpu@yahoo.com

\section{РЕГІОН ПОСТРАДЯНСЬКОЇ СХІДНОЇ ЄВРОПИ В ЗОВНІШНІЙ ПОЛІТИЦІ ВЕЛИКОЇ БРИТАНІЇ У КОНТЕКСТІ

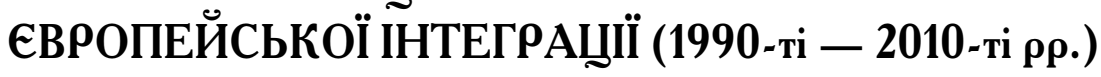

У статті представлено результати дослідження проблеми формування та реалізації східноєвропейської політики Великої Британії у 1990-х - 2010-х роках. Показано особливості політики Європейського Союзу щуодо пострадянських країн Східної Європи (Росії, Украӥни, Білорусі, Молдови), роль Великої Британії у цььому прочесі. Автор стверджує, що зовнішня політика Великої Британії щчодо держав Східної Європи, зокрема, пострадянського простору, розвивалася в контексті загальної політики Заходу й відчувала сильний вплив російського чинника. Стратегічним завданням зовнішньої політики СС у нових геополітичних умовах стало забезпечення стабільності й безпеки на Сході Свропи, просторах колишнього СРСР, насамперед у краӥнах найближчої периферії - Росії, Україні, Білорусі й Молдові. Незважаючи на вагому стратегічну роль регіону Східної Свропи, його міжнародне значення $Є C$ Велика Британія завжди недооцінювали. Остаточне послаблення впливу Великої Британії на східноєвропейську політику $Є С$, що наступить унаслідок ї̈ виходу з об'єднання («Вreхіt»), матиме негативні наслідки для євроінтеграчійних прагнень краӥн субрегіону.

Ключові слова: Велика Британія, Східна Свропа, пострадянські краӥни, європейська інтеграчія, Свропейський Союз, Спільна зовнішня політика й політика безпеки, Свропейська політика сусідства, Східне партнерство. 


\section{Andrii Hrubinko \\ Doctor of History, Associate Professor \\ Ternopil National Economic University \\ 11, Lvivska Street, Ternopil, 46000, Ukraine \\ E-mail: gav_tnpu@yahoo.com}

\section{THE POST-SOVIET EASTERN EUROPE REGION IN THE UNITED KINGDOM'S FOREIGN POLICY IN THE CONTEXT OF EUROPEAN INTEGRATION (1990s-2010s)}

The article presents the results of the study problem of formation and implementation of Eastern European policy by Great Britain in the 1990s 2010s. The features of the European Union's policy towards the post-Soviet countries of Eastern Europe (Russia, Ukraine, Belarus, Moldova) and the role of Great Britain in this process are shown. The author argues that Britain's foreign policy towards the countries of Eastern Europe, in particular the postSoviet space, developed in the context of the general policy of the West and felt strongly influenced by the Russian factor. The strategic objective of the EU's foreign policy in the new geopolitical environment has been to ensure stability and security in Eastern Europe, the former USSR, especially in the countries near the periphery. In 2002, the UK Government initiated the creation of a European Neighborhood Policy Mechanism. However, it was controversial. The democratic revolutions in Georgia and Ukraine in 2003-2004 did not lead to a radical revision of their relations with the EU. The intensification of tensions in the relations between the European Union, certain Western powers (in particular the United Kingdom) and Russia in the second half of the 2000s contributed to a certain intensification of their policy towards the post-Soviet states. However, the British governments have moved away from leading positions in the European Union integration policy and have taken a passive role in the Eastern Partnership program by giving the initiative to Germany.

Despite the important strategic role of the Eastern European region, its importance to the EU and the United Kingdom has always been underestimated. It is concluded that the underestimation of security threats in Eastern Europe, along with the common problems of the Alliance's development, have led to its inability to guarantee security at its eastern borders without the support of the US and NATO. The result is the United Kingdom, whose government, in the face of leaving the EU and losing influence in the Central Eastern Europe region, is interested in reorienting the United States to European security issues and stepping up NATO activities in Europe. 
With the UK leaving the EU, only real channel for its influence on the international situation in Eastern Europe will be US-backed NATO mechanisms. The completion of the Brexit process will weaken the position of Eastern European countries in their desire to become full members of the European Union.

Keywords: the United Kingdom, Eastern Europe, post-Soviet countries, European integration, European Union, Common Foreign and Security Policy, European Neighborhood Policy, Eastern Partnership.

Необхідність дослідження передумов, сутності і прогнозування наслідків сучасних складних трансформацій у функціонуванні Європейського Союзу й загалом європейської регіональної системи міжнародних відносин, невід'ємним елементом яких є вихід Великої Британії з цього об'єднання (відомий як «Brexit»), зумовлює важливість історичного аналізу досвіду формування й реалізації іiі зовнішньої політики в контексті новітніх процесів європейської інтеграції у межах 1990-х — 2010-х років. 3 огляду на значення субрегіону Східної Європи як сучасного центру міжнародної нестабільності у зв'язку з російсько-українським конфліктом і перманентний процес просування України шляхом долучення до регіональної інтеграції, особливої актуальності набуває дослідження історії східноєвропейського напряму зовнішньої політики Великої Британії, з проекцією на історичні особливості реалізації відповідного вектора міжнародного впливу Європейського Союзу.

Аналіз стану наукової розробки проблеми дослідження підтверджує недостатній рівень іiі представлення в історіографії. Серед іiї українських дослідників відзначимо В. Крушинського, А. Мартинова, Н. Яковенко, А. Грубінка, російських британістів Т. Андрєєвої, А. Громико, Н. Капітонової, західних учених Ч. Гранта, Д. Петерса, Дж. Ховарта, К. Язвінскі. У більшості їхніх публікацій аспект східноєвропейської політики Великої Британії піднімається в контексті розгляду загальної проблематики міжнародної політики Свропейського Союзу.

Створення Свропейського Союзу на початку 1990-х рр., що співпало iз завершальним етапом дезінтеграційних процесів на Сході Свропи i розпадом СРСР, поставило на порядок денний об'єднання необхідність розробки стратегії відносин із державами пострадянського простору. Визнання і налагодження взаємин із країнами колишнього СРСР відбувалося в непростих міжнародних умовах, ускладнювалося невизначеністю подальшого розвитку системи міжнародних відносин.

Логіка геополітичних трансформацій, об'єктивні соціально-економічні чинники та зрештою комплекс історичних стереотипів міжнародної політики зумовили поділ географічно широкого регіону Центрально- 
Східної Свропи (далі - ЦСС) як периферії ЄС на дві сфери: 1) держави колишні сателіти Радянського Союзу, яким було надано можливості розвивати вищий рівень відносин із СС із перспективою набуття членства; 2) новостворені держави, які утворилися на уламках СРСР у 1991 році і географічно належать до Європи (Росія, Україна, Білорусь, Молдова, держави Балтії). 3 другої когорти особливу групу становили держави Балтії, які ще на завершальному етапі існування СРСР знайшли підтримку в Свропейському Співтоваристві. Це досить швидко призвело до їх політичного зарахування в першу групу й логічно завершилося набуттям повноправного членства в ЄС у 2004 році. 3 пострадянських країн завжди виділялася європейсько-азійська Росія, яка була визнана правонаступницею СРСР і зберегла вагомий геостратегічний вплив, що давало можливість дистанціюватися від колишніх «братніх республік» і розвивати відносини з СС у статусі субрегіонального лідера. Формування політики $\mathrm{CC}$ щодо східноєвропейських пострадянських країн і налагодження співробітництва 3 ними стало невід'ємною частиною його зовнішньої політики, особливо після надання перспективи членства державам Центральної Європи і Балтії.

Незважаючи на очікувану й апріорі бажану в умовах протистояння «холодної війни» перемогу, стрімка ліквідація Східного блоку, особливо розпад СРСР, стали певною несподіванкою для західних політичних еліт. Підтримуючи до останнього його цілісність, британське керівництво спершу не розглядало можливість співпраці з незалежними пострадянськими державами, проголошення яких трактувалося як виникнення загрози міжнародній безпеці. Втрата усталених міжнародних орієнтирів викликала непевність і тривогу. Згадаємо тісні контакти М. Тетчер із М. Горбачовим. Британський прем'єр-міністр була одним із головних пропагандистів «перебудови» на Заході й негативно сприймала дезінтеграційні процеси в Радянському Союзі. Прем'єр-міністр Великої Британії наголошувала на необхідності підтримки Заходом реформаторських зусиль радянського керівництва. Згодом у мемуарах М. Тетчер зазначала, що недооцінювала слабкість Радянського Союзу і вірила в можливість існування некомуністичного СРСР ${ }^{1}$. Як наслідок британський уряд до останнього підтримував радянську владу. Така політика Кабінету міністрів входила в суперечність із суспільними настроями й думкою експертів у самій Великій Британії, які все більшу увагу звертали на відцентрові тенденції в радянських республіках. Після розпаду СРСР у грудні 1991 р. Захід більше не мав можливості нехтувати об'єктивними міжнародними реаліями.

Політика Європейського Економічного Співтовариства (СЕС) щодо території пострадянського простору почала формуватися в заключні роки 
існування СРСР і здійснювалася в унісон із політикою його провідних держав-членів у рамках механізму Свропейського політичного співробітництва. 18 грудня 1989 р. підписано перший договір ЄЕС із СРСР «Угоду про торгівлю, економічне та комерційне співробітництво» терміном на десять років. У 1991 році СЕС (у тому числі уряд Великої Британії) виділив продовольчу допомогу СРСР на загальну суму 750 млн екю. Ще 400 млн екю виділено на технічну допомогу. Саміт Свропейської Ради в Люксембурзі 28-29 червня 1991 р. засвідчив повну підтримку від лідерів держав ЄЕС президенту й уряду Радянського Союзу. СЕС вимагав припинити застосування сили в Литві для придушення антивладних виступів 3 можливим припиненням співпраці з СРСР. Водночас в об'єднанні не відмовлялися від планів підписання великих угод з Москвою щодо політичної і культурної співпраці. СЕС прагнув отримати стабільного партнера на східному кордоні. У 1991 році розпочато програму TACIS (Technical Assistance to the Commonwealth of Independent States), спрямовану на фінансування проектів розвитку демократії і переходу до ринкової економіки, поширену на країни СНД.

У Європі були готові розвивати співробітництво з СРСР. Однак розпад останнього в грудні 1991 р. визначив нові міжнародні реалії. На надзвичайному засіданні міністрів закордонних справ держав ЄЕС 16 грудня 1991 р. зафіксовано готовність визнати усі нові держави, утворені внаслідок розпаду Радянського Союзу, і встановити дипломатичні відносини за умови визнання ними принципів міжнародного права, зобов'язань із роззброєння, ядерного нерозповсюдження й регіональної безпеки². Лідери держав-членів ЄЕС 23 грудня 1991 р. привітали створення СНД і визнали правонаступність Російської Федерації за зобов'язаннями Радянського Союзу. Наступним кроком стало визнання державної незалежності колишніх радянських республік, що відбулося 31 грудня 1991 року. У січні 1992 року Європейська Комісія прийняла рішення переглянути свої відносини з ними (офіційно - «нові незалежні держави», ННД) і вирішила замість адаптації договору 1989 року з СРСР до нових умов піти шляхом підписання окремих угод із кожною з них.

Одним із стратегічних завдань зовнішньої політики Свропейського Союзу в нових геополітичних умовах стало формування зони стабільності й безпеки на Сході Свропи і просторах колишнього СРСР. Насамперед це стосувалося країн найближчої східної периферії - Росії, України, Білорусі й Молдови. Захід цікавило встановлення контрольованих і прогнозованих процесів розвитку демократії, формування ринкових відносин у цих державах, їх інтеграції до сучасної міжнародної політичної та економічної систем, адже вони після надання перспектив членства державам Центральної Європи і Балтії автоматично ставали найближчими сусідами 
ЄС. Тому він ініціював ряд заходів міжнародної підтримки пострадянським державам. Однак, на відміну від держав ЦСС, ЄС і його члени (у тому числі Велика Британія) не поспішали виділяти кошти для допомоги пострадянським країнам.

Інтереси Великої Британії у відновленні пострадянських держав узгоджувалися із загальною лінією євроатлантичного співтовариства. Специфічно британський інтерес лежав у геополітичній площині недопущення надмірного посилення Росії на фоні відродження об'єднаної Німеччини і створення в перспективі домінуючого в Європі альянсу Німеччина-Франція-Росія, який міг би нівелювати британсько-американський вплив на континенті. Водночас Велику Британію, як і Захід загалом, цікавило збереження Росії як єдиного прогнозованого центру сили на теренах колишнього СРСР. Це стало головним чинником шаленого міжнародного тиску на українську владу щодо ядерного роззброєння. Як показали сучасні реалії міжнародної безпеки, однією з головних загроз якій є Росія, така політика провідних західних структур і держав початку 1990-х років була вельми недалекоглядною.

Важливий етап для визначення загальної стратегії Європейського Союзу щодо держав пострадянського простору випав на чергове головування Великої Британії у Раді СС у червні - грудні 1992 року. Декларація щодо Росії та СНД, прийнята 12 грудня 1992 року на саміті Європейської Ради в Единбурзі, узагальнювала принципи побудови відносин $\mathrm{CC}$ із пострадянськими державами. Аналіз тексту документа дає можливість виділити базові елементи довгострокової стратегії $\mathrm{С} \mathrm{i}$ держав Західної Свропи щодо згаданого регіону:

1) пріоритет у відносинах із пострадянськими державами надавався Росії, яка як основна регіональна потуга повинна була гарантувати безпеку в нестабільному пострадянському регіоні. На початку 1990-х років представники західних держав навіть давали непублічні обіцянки іï керівництву не розширювати НАТО на Схід і не приймати до складу організації пострадяські держави ${ }^{3}$. На Заході були зацікавлені в тому, щоб хтось ніс відповідальність за виконання міжнародних зобов'язань СРСР, включно з угодами про роззброєння, забезпечував виплати величезних (понад 70 млрд. дол. США) боргів. Це міг тоді здійснити лише уряд Росії, що зумовило визнання ії як правонаступниці СРСР, надання основної частки фінансової допомоги;

2) для усіх пострадянських держав надано статус простих партнерів ЄС без диференціації і перспектив членства, навіть асоційованого, яке на той час вже було надане багатьом державам ЦСС. При цьому фактично урівнювалися у статусі Росія, яка ніколи не ставила завдання вступити до $€ С$, країни європейської частини колишнього СРСР (Україна, Білорусь і 
Молдова), Закавказзя і Центральної Азії, що свідчило про нехтування інтересами, значенням і можливостями першої групи країн;

3) передбачалося налагодження довгострокового торговельного, інвестиційного й технічного співробітництва. Однак не йшлося про розвиток системної взаємодії у питаннях зовнішньої політики й безпеки, залучення пострадянських держав до міжнародних акцій ЄС і військовополітичної кооперації, що виявило його невпевненість у своїх можливостях на міжнародній арені, недооцінку значення вказаних держав. Підтвердженням такого висновку стало обрання основним інструментом політики щодо держав СНД укладення звичайних рамкових угод про партнерство і співробітництво (УПС) терміном на десять років, які були підписані окремо 311 країнами колишнього СРСР, мали загальний характер і реально мало до чого зобов'язували обидві сторони.

У відносинах $\mathrm{CC}$ із пострадянськими державами мали місце специфічні проблеми й розходження. Зокрема, у взаєминах із Росією головними проблемними періодами стали чеченські війни 1994-1996 років і 1999 - початку 2000-х років, коли Захід засудив дії Москви в Чечні. СС двічі призупиняв фінансові програми технічної допомоги країні. У період першої війни в Чечні призупинялася ратифікація УПС. Політична напруга між сторонами спостерігалася в 1997 році внаслідок розширення НАТО на схід Європи та в березні-червні 1999 року під час бомбардування Югославії міжнародною коаліцією держав Альянсу. Тому візит Т. Блера до Росії 10-11 березня 2000 року викликав негативну реакцію значної частини британської громадськості. Після обрання В. Путіна президентом Росії 26 березня 2000 року глава Форін офісу Р. Кук висловив глибоке занепокоєння ситуацією в Чечні і зазначив, що вона не дає можливості працювати з Росією як 3 партнером ${ }^{4}$. Міжнародні інтереси Кремля, які активно проявлялися в регіоні Східної Свропи і Балкан, почали все більше входити в суперечність із розширенням геополітичного впливу ЄС та інтересами провідних європейських держав.

На теренах пострадянської Східної Свропи не було держави, яка б стала у певній мірі зразком демократичного реформування та антиподом Росії у відносинах із Заходом. В Україні, Молдові і Білорусі, як і в Росії, в умовах економічної кризи та соціального зубожіння на середину 1990-х pp. закріпилися по своїй суті антидемократичні корумповані державні режими, очолювані представниками колишньої радянської політичної і господарської верхівки, зрощені з новим капіталом (олігархатом) специфічного місцевого зразка. Політична верхівка України й Молдови декларувала європейський напрям зовнішньої політики, реально орієнтуючись на традиційні зв'язки з Росією. Свою специфіку політичного й соціальноекономічного розвитку мала Білорусь, керівництво якої на чолі 3 
О. Лукашенко проводило відкриту проросійську політику, нехтуючи розвитком співпраці з СС.

Основною проблемою Молдови (найбіднішої країни європейської частини колишнього СРСР), окрім економічних негараздів та несформованої демократичної політичної системи, стали проблеми територіальної цілісності (конфлікт у Придністров'ї). Наявність тісних культурних зв'язків із Румунією з одного боку схиляла населення країни до орієнтації на відносини з ЄС. Однак економічна, насамперед енергетична, залежність від Росії і зв'язки в рамках СНД, відсутність зрілої проєвропейської політичної еліти створили дихотомію стратегічних напрямів зовнішньої політики цієї держави, між якими вона намагалася тривалий час балансувати 5 . Як наслідок до початку 2000 -х років суттєвих кроків у напрямі розвитку співпраці Молдови і ЄС не відбулося. Країна тривалий час не привертала значної уваги Заходу. Промовистим став факт, що окремого посла Великої Британії до Молдови призначено лише у 2002 році. До цього функції посла в Кишиневі за сумісництвом виконували по черзі британські посли в Росії і Румунії.

Відмова ЄС продовжувати ратифікацію УПС з Білоруссю після наростання авторитарних тенденцій у цій пострадянській державі стала першою ознакою посилення напруги в непростих відносинах сторін. Нове керівництво Білорусі, що прийшло на зміну демократичному правлінню у 1994 році, ніколи не ставило питання про вступ до СС, намагаючись рішуче протистояти демократичним віянням з Свропи. Безпосередньою причиною початку погіршення відносин між сторонами стало проведення в Білорусі референдуму 1996 року про внесення змін до Конституції, унаслідок яких республіка з парламентсько-президентської стала президентською. У жовтні того ж року посли Великої Британії, Франції, ФРН, Італії направили до МЗС Білорусі заяву, в якій від імені СС висловили стурбованість загрозою порушення конституційного ладу й зазначили, що шанси держави на активну роль у Європі й поглиблення відносин 3 об'єднанням під загрозою ${ }^{6}$ Ситуація в Білорусі розглядалася на засіданні Ради міністрів закордонних справ СС 15 вересня 1997 року, підсумком якого стало рішення про запровадження обмеження на контакти з цією країною. Чітка політична лінія СС і його держав-членів на засудження тоталітарних тенденцій у Білорусі втілилася в запровадженні обмежень на офіційні контакти на найвищому й високому рівнях, візових обмежень для білоруських посадовців і секторальних економічних санкцій. Наявність практично в центрі Свропи модернізованого релікту радянського тоталітарного режиму турбувало Свроспільноту. Однак відсутність стратегічної зброї, наявність стабільного й безпечного внутрішнього суспільного середовища, яке гарантував режим О. Лукашенка, закритість 
кордонів для міжнародних нелегальних мігрантів і обмеженість зовнішньої політики регіоном СНД робило Білорусь загалом безпечною сусідкою для ЄС.

3 огляду на нові виклики міжнародній безпеці та економічну кризу наприкінці 1990-х років відбулася розробка нових поглиблених механізмів реалізації політики СС щодо держав пострадянського простору, серед яких пріоритетними були Росія та Україна. Одним із таких механізмів стали спільні стратегії — концептуальні документи довгострокового співробітництва ЄС 3 третіми країнами, перші з яких були ухвалені Свропейською Радою щодо Росії (4 червня) та України (11 грудня) 1999 року. Активна участь Росії у міжнародних зусиллях з врегулювання конфлікту на Балканах у 1999 році, близька перспектива спільного кордону після чергового розширення $\mathrm{CC}$, потреба в російських енергоресурсах змусила євроінституції та уряди держав-членів піти на зближення з Москвою.

Підходи британського керівництва до політики щодо Росії у 1990-х роках співпадали з партнерами по ЄС. У відносинах з пострадянськими державами Східної Свропи уряди Великої Британії надавали пріоритет Росії, визнавши іiі регіональним лідером. За оцінками Н. Капітонової, Дж. Мейджор більш ніж інші західні лідери демонстрував підтримку російського керівництва в драматичний період загострення внутрішньополітичної ситуації у Росії у 1993 році ${ }^{7}$. У питанні розширення НАТО на Схід Європи Лондон намагався виважено підходити до діалогу з Москвою. Британське керівництво підтримувало розвиток співпраці Росії з Альянсом, іiі включення до складу учасників Великої сімки, налагодження відносин з Європейським Союзом. Однак політична нестабільність та економічні проблеми, посилення шовінізму викликали на Заході певне розчарування й перестороги щодо можливості відновлення державного утворення імперського типу. Тому від середини десятиліття Велика Британія намагалася налагодити контакти 3 іншими державами колишнього СРСР, насамперед з Україною.

Політику сприяння розвитку відносин із Росією продовжив уряд лейбористів. На нетривалий період бомбардувань силами НАТО Югославії у 1999 році двосторонні міждержавні контакти на високому рівні було припинено. Початок другої війни в Чечні суттєво не вплинув на відносини Росії як з Великою Британією, так і з ЄС загалом. Форін офіс публічно обмежився висловлюванням стурбованості. Після обрання президентом В. Путіна у березні 2000 року Т. Блер пішов на встановлення тісних особистих контактів із новим російським лідером. Британський політичний істеблішмент був ладний навіть виправдати політику російських партнерів у Чечні заради посилення власного впливу в міжнародній 
політиці, намагаючись зміцнити позиції у взаєминах із французьконімецьким «ядром» СС. Спостерігалося суперництво Великої Британії і Німеччини за інвестиційні контракти на транспортування російських енергоносіїв до Європи. Наприкінці 2001 року Т.Блер охарактеризував відносини між Великою Британією й Росією як «найтісніші за багато років» ${ }^{8}$. Виникли умови для позиціонування Великої Британії як головного європейського партнера Росії. Лондонський Сіті став популярним місцем для притоку російських капіталів.

ЄС на той час розглядався керівництвом Росії як можлива і прийнятна альтернатива НАТО, один із механізмів протистояння однополярному світоустрою. Однак спроби Росії реалізувати спільні з СС інституційні проекти у сфері безпеки закінчилися на рівні декларацій. За рішенням Римського саміту ЄС-Росія від 6 лютого 2003 року схвалено ідею формування спільного економічного, безпекового і гуманітарного простору, яка не була реалізована. Свропейський Союз все більше розглядався російським керівництвом як геополітичний суперник, насамперед на пострадянському просторі, який Москва традиційно вважає сферою своїх пріоритетів. Свропа зайняла пасивно-лояльну позицію до формування в Росії владного механізму керованої демократії і посилення впливу в системі європейської безпеки, що стало одним з чинників її наступної глибокої кризи.

Початок процесу найбільшого розширення СС за всю його історію змусив його інституції і держави-члени більш чітко визначитися із досі аморфним та відмінним статусом численних держав, які стали найближчою периферією об'єднання. До основних завдань ЄС у відносинах із сусідніми країнами входило формування периметру політично стабільних та економічно розвинених держав, які б дотримувалися демократичних ринкових цінностей і були дружніми Заходу. Водночас було важливо згладити ефект від паузи в подальшому розширенні $\mathrm{CC}$, щоб не втратити його привабливості для держав, які прагнули вступу (насамперед України й Молдови $)^{9}$. На відміну від держав Середземномор'я, які з 1995 року розвивали відносини з СС у рамках «Барселонського процесу», ці дві держави, а також обкладена санкціями Білорусь, не були включені у жоден із регіональних вимірів зовнішньої політики об'єднання.

В авангарді формування нового зовнішньополітичного механізму $\mathrm{CC}$ невипадково стояла Велика Британія, уряди якої традиційно підтримували розширення зони впливу Свропейського Союзу, та Швеція, керівництво якої надавало великого значення східноєвропейській політиці. На початку 2002 року міністр закордонних справ Великої Британії Дж. Стро направив листа міністру закордонних справ Іспанії, яка головувала в Раді $€ C$, Й. Піке із зверненням про необхідність офіційного розгляду стану й 
перспектив відносин із Молдовою, Білоруссю та Україною. Пропонувалося надати їм статус «особливих сусідів» Свропейського Союзу ${ }^{10}$. Такий статус, на думку міністра, мав передбачати перспективи вільної торгівлі, розвиток відносин з питань прикордонного контролю, безпеки і внутрішніх справ. Про перспективи членства в $\mathrm{CC}$ не йшлося. Цей прагматичний план ліг в основу нового східного напряму регіональної зовнішньої політики Союзу. Іншими трьома напрямами були Середземноморський i Північний виміри та Західні Балкани. Глава МЗС Швеції А. Ліндт пропонувала включити Росію до східного виміру європейського сусідства, але проти виступила Польща. Принципова позиція Варшави полягала в необхідності надання перспектив членства в СС для східних сусідів, серед яких Росія не була претендентом.

Британську ініціативу розглянули 15 квітня 2002 року в Люксембурзі на засіданні Ради СС із зовнішніх відносин. Верховному представнику 3 питань зовнішньої політики і політики безпеки X. Солані і Комісару із зовнішніх відносин британцеві К. Паттену доручили розробити пропозиції для розгляду Свропейської Ради. Рада $С С$ пропонувала розробникам врахувати різний рівень політичних та економічних відносин об'єднання із східними сусідами. Європейська політика сусідства як новий механізм зовнішньої політики ЄС охопив 16 держав. Окрім трьох держав Східної Європи вона стосувалася Південного (окрім Лівії) і Східного Середземномор'я та Південного Кавказу.

Ініціатива британського уряду лягла в основу офіційної позиції Комісії ЄС, оприлюдненої 11 березня 2003 року у Посланні до Ради СС та Свропарламенту «Ширша Свропа - Сусідні країни: Нова структура взаємовідносин з нашими східними та південними сусідами». Свропейський Союз заявляв про рішучість не допустити проведення в Свропі нових розмежувальних ліній, сприяти стабільності та процвітанню в межах і за межами об'єднання. Країнам-сусідам пропонували частку внутрішнього ринку, поступову інтеграцію й лібералізацію (елементи вільного руху осіб, товарів, послуг і капіталів). Як зазначали європейські чиновники, пріоритет у відносинах із державами-сусідами із Східної Європи (т.зв. «Західні нові незалежні держави») надавався Україні, яка висловила прагнення стати членом ЄС у перспективі. Об'єктивно Україна не мала конкурентів, адже Росія відмовилася приєднатися до політики сусідства. Відносини $\mathrm{CC}$ із Білоруссю були формальними через критику політики режиму О. Лукашенка, а Молдова становила загрозу безпеці в регіоні через Придністровський конфлікт.

Водночас формально статус усіх об'єктів політики ЄС був рівним. Держави, які бажали стати членами об’єднання (наприклад, Україна) були в однаковому становищі з учасниками програми, які апріорі не мали 
шансів на членство через географічний чинник (наприклад, Ізраїль). Таке зрівняння в статусі й можливостях змусило держави-партнери $Є С$ сприймати політику сусідства як альтернативу членства. Представники $\mathrm{CC}$ наголошували, що нова політика повинна здійснюватися диференційовано, враховувати різні можливості, етапи реформ та рівні економічного розвитку держав-сусідів. Таку індивідуалізацію планувалося реалізовувати на основі окремих Планів дій для кожної держави-партнера окремо.

На практиці Свропейська політика сусідства, особливо в її східному вимірі, виявилася неефективним зовнішньополітичним механізмом. У сфері безпеки $Є \mathrm{C}$, обмежений у військовому плані, так і не зміг істотно вплинути на вирішення жодного з тривалих конфліктів на своїй периферії, наприклад, у Придністров’і, Західній Сахарі й Палестині. Політику сусідства щодо пострадянських держав Східної Свропи звели до надання обмеженого фінансування за програмами технічної допомоги, визначення односторонніх «домашніх завдань» щодо приведення у відповідність законодавства, політичної та економічної систем до норм ЄС. Головний акцент зроблено на розвиток транскордонного співробітництва й облаштування східних кордонів.

Знаковою для виявлення мети політики сусідства $\mathrm{CC}$ на східному напрямі стала ініціатива уряду Великої Британії щодо створення міграційних зон безпеки на території сусідніх держав. Такі зони як території тимчасового утримання нелегальних мігрантів із Афганістану, Іраку та інших країн «третього світу», які усілякими способами намагалися дістатися Свропи, пропонувалося створити в Марокко, Сомалі, Росії та Україні. Через пів року Велика Британія і СС мали прийняти рішення про допуск цих мігрантів на свою територію згідно з квотами. Прогнозуючи негативну реакцію вказаних держав на таку ініціативу, Свропейська Рада в Салоніках у червні 2003 року відхилила британську ідею. Зазначена пропозиція відобразила істинне значення країн-сусідів для провідних держав ЄС як бар'єру й відстійника для нової хвилі нелегальної міграції.

Європейська політика сусідства стала вимушеною реакцією Європейського Союзу на зміну зовнішнього середовища після чергового розширення, узагальненою стратегією розбудови відносин із країнами найближчої периферії. Велика Британія, виступивши формальним ініціатором новели, проявила єдність позиції з європейськими партнерами щодо неможливості подальшого розширення СС у найближчій перспективі на країни пострадянської Східної Свропи. На британську позицію вплинули такі головні фактори: ситуативність і варіативність державних інтересів у цьому регіоні; небажання додатково загострювати відносини з європейськими партнерами, насамперед Францією і ФРН; покращення відносин із Російською Федерацією. Недостатній інтерес британського уряду до 
країн Східної Європи варто розглядати в контексті загальних тенденцій у зовнішній політиці ЄС. Промовистим став факт, що у презентованій у грудні 2003 року Х. Соланою Європейській стратегії безпеки східні сусіди згадуються побіжно. Натомість значну увагу приділено необхідності врегулювання арабо-ізраїльського конфлікту, розвитку співробітництва в рамках «Барселонського процесу» й необхідності зміцнення відносин із арабським світом ${ }^{11}$. Зрештою високий рівень проблемності розвитку пострадянської Східної Свропи не надавав оптимізму західним урядам. Навіть «кольорові революції» в Грузії та Україні у 2003-2004 pp. не спричинили кардинального перегляду політики СС у регіоні. Новою тенденцією зовнішньої політики СС стало посилення інтересу до Південного Кавказу.

Реальна практична робота 3 втілення програм у рамках політики сусідства щодо країн Східної Свропи, зокрема старт проектів транскордонного співробітництва, розпочалася напередодні приєднання до ЄС Болгарії і Румунії, коли Єврокомісія оприлюднила повідомлення «Про посилення Європейської політики сусідства» від 4 грудня 2006 року. Документ робив наголос на необхідності інтенсифікації співпраці з країнами-сусідами. Передбачалося часткове спрощення візового режиму, розширення грантової допомоги для неурядових організацій і науковців, у тому числі надання доступу до програм СС. Закритість кордонів Великої Британії від шенгенської зони робило такі новели для співпраці цієї країни з сусідами СС практично неактуальними. У частині політичного співробітництва державам-сусідам надано право приєднуватися до заяв ЄС у рамках його Спільної зовнішньої і безпекової політики. Передбачено загальну можливість координації зусиль на рівні міжнародних організацій і форумів, участь у врегулюванні конфліктів ${ }^{12}$. Не вражала новаторством висунута керівництвом Німеччини у 2007 році ініціатива під умовною назвою «Європейська політика сусідства Плюс», головною новелою якої стало допущення можливості переходу до відносин асоціації з країнами, які демонструють прогрес у зближенні з СС.

У другій половині 2000-х років міжнародна ситуація на Сході Європи зазнала відчутних змін. Насамперед це було пов'язано з активізацією прозахідних політичних сил у країнах пострадянського простору. У процесі реалізації конкретних програм співпраці $\mathrm{CC}$ із східноєвропейськими країнами відбувалося реальне формування окремого виміру політики сусідства. Вступ у 2007 році до ЄС Болгарії і Румунії безпосередньо наблизив об'єднання до чорноморського регіону. Ініціатива СС «Чорноморська синергія» щодо співробітництва з країнами відповідної акваторії, влючаючи Росію, була активізована Єврокомісією у 2007 році і стала провісником програми «Східне партнерство». Російська сторона відмовилася від участі в ініціативі. Після «кольорових революцій» $\mathrm{CC}$ і Росія остаточно стали суперниками за вплив на Східну Європу. 
3 другої половини 2003 року спостерігалося стійке наростання напруги у відносинах Великої Британії і Росії. На відміну від ряду держав Західної Європи, насамперед ФРН, Франції та Італії, Велика Британія 3 огляду на мінімальну залежність від російських енергоресурсів і союзницькі відносини із США зазнавала значно меншого впливу цього східного фактора на свою зовнішню політику. У британських політичних колах утвердилося переконання, що Росія $є$ залежною від ЄС як найбільшого ринку збуту своїх енергоресурсів. Тому країни Європи повинні проводити спільну енергетичну політику, подолавши розбіжності інтересів, які послаблюють їх та ЄС загалом. У рішенні спеціального засідання Комітету закордонних справ Британського парламенту від 25 листопада 2007 року уряду було рекомендовано визначити проблеми розробки єдиної стратегії $\mathrm{CC} \mathrm{у} \mathrm{відносинах} \mathrm{з} \mathrm{Росією} \mathrm{пріоритетом} \mathrm{на} \mathrm{найближчу}$ перспективу. Енергетична залежність від Москви й підтримка Вашингтона дозволила Лондону зайняти критичну позицію щодо Росії.

Новий виток напруги в російсько-британських відносинах зумовлений, серед іншого, посиленням прозахідних настроїв на пострадянському просторі. Справа про вбивство в Лондоні колишнього агента ФСБ Олександра Литвиненка в листопаді 2006 року й відмова Росії екстрадувати до Великої Британії підозрюваного у вбивстві Андрія Лугового, взаємна висилка дипломатів і фактичне призупинення контактів МЗС обох держав, обмеження видачі британських віз російським громадянам, шпигунські скандали і закриття відділів Британської Ради в регіонах Росії сформували картину міждержавних взаємин другої половини 2000-х років. Лондон використовував багатосторонню дипломатію для привернення уваги європейських партнерів до посилення авторитаризму в Росії, невиконання нею міжнародних зобов'язань щодо розвитку демократії і дотримання прав людини. Погіршення російсько-британських відносин відображало загальну тенденцію ускладнення взаємин Росії із Заходом.

Апогеєм напруги між сторонами в другій половині десятиліття стала «П'ятиденна війна» у серпні 2008 року між Грузією й Росією. СС здійснив не надто успішну спробу застосувати механізми Спільної зовнішньої і безпекової політики. Британське керівництво взяло активну участь у надзвичайному саміті Свропейської Ради 1 вересня 2008 року, на якому прийнято т.зв. «план Саркозі» з урегулювання конфлікту. В СС засудили російське рішення визнати незалежність самопроголошених республік Абхазії і Південної Осетії. Під час обговорення проявилися розбіжності між членами об'єднання. Велика Британія, Швеція, Польща, держави Балтії висунули вимогу докорінного перегляду взаємин із Росією і застосування санкцій. Німеччина і Франція зайняли помірковану позицію, а прем'єр-міністр Італії С. Берлусконі засудив діяльність Президента Грузії 
М. Саакашвілі ${ }^{13}$. Керівництво Великої Британії вкотре підняло питання диверсифікації джерел постачання енергоресурсів до Європи, подвоєння міжнародних зусиль щодо створення єдиного європейського ринку газу та електроенергетики. Результатом діяльності СС стала поміркована угода, підписана 8 серпня 2008 року в Москві його керівництвом як посередником і Президентом Росії Д. Медведьєвим, яка містила положення про відхід російських військ з Грузії, за винятком території Абхазії і Південної Осетії. Фактично ЄС схвалив відділення самопроголошених територій від Грузії і замороження конфлікту.

Британські експерти оцінювали ситуацію досить критично. У пресі висловлювалися думки про те, що події у Грузії виявили нерішучість СС. Прем'єр-міністра Г. Брауна британська преса звинуватила в нездатності вести рішучу зовнішню політику ${ }^{14}$. Він, на відміну від А. Меркель та Н. Саркозі, не відвідав Грузію, відправивши туди міністра закордонних справ Д. Мілібенда. Натомість активну позицію проявив лідер опозиційних консерваторів Д. Кемерон, який здійснив короткочасний візит до Тбілісі і вже тоді припустив, що Росію буде виключено з Великої вісімки, та закликав надати Грузії членство в $\mathrm{HATO}^{15}$.

Загалом міжнародна ситуація навколо російсько-грузинського конфлікту 2008 року виявила неготовність європейських лідерів адекватно і своєчасно реагувати на зміни в системі міжнародних відносин. Напружені російсько-британські взаємини робили неможливим виконання Лондоном посередницьких функцій. Події навколо конфлікту зафіксували тенденцію зменшення впливу Сполученого Королівства на регіон Східної Європи, де набирала впливу ФРН.

Зважаючи на загальну неефективність політики сусідства в попередньому форматі, у 2008 році Свропейський Союз запровадив дві окремі ініціативи - «Союз для Середземномор'я» і «Східне партнерство». Окрема політика $\mathrm{CC}$ для шести пострадянських держав (Білорусь, Молдова, Україна, Азербайджан, Вірменія і Грузія) стала відповіддю прихильників регіону, насамперед Польщі і Швеції, на ініціативу президента Франції Н. Саркозі щодо поглиблення співпраці СС з державами Південного Середземномор'я (травень 2008 року). «Східне партнерство» як напрям зовнішньої політики СС набув особливої актуальності після російсько-грузинської війни. Європейська Рада на саміті 19-20 червня 2008 року звернулася до Свропейської Комісії з проханням підготувати відповідні пропозиції. 3 грудня 2008 року оприлюднено офіційне повідомлення Європейської Комісії до Європейського Парламенту і Європейської Ради «Східне партнерство». Програма передбачала перспективу підписання угод про асоціацію, лібералізацію візового режиму і створення комплексної зони вільної торгівлі з кожною державою, енергетичну 
співпрацю, підтримку реформ. Реалізація «Східного партнерства» мала здійснюватися паралельно із стратегічним партнерством з Росією. Участь Білорусі в програмі залежала від розвитку їі відносин із СС. Передбачено участь держав-партнерів у місіях і операціях під егідою Союзу. Відбувся логічний розподіл середземноморського і східноєвропейського напрямів зовнішньої політики $Є С$, але такий рівень поглиблених відносин 3 об'єднанням не передбачав членства. «Східне партнерство» введене в дію 7 травня 2009 року під час саміту Європейської Ради в Празі.

У процесі реалізації згаданих ініціатив у рамках політики сусідства спостерігалася пріоритетність середземноморського напряму зовнішньої політики $\mathrm{CC}$ над східноєвропейським, що засвідчили обсяги фінансування. У 2007-2013 роках в рамках Інструменту європейського сусідства й партнерства на співробітництво у басейні Середземномор'я було виділено 16 млрд євро. У той час, як на «Східне партнерство» у 2008-2013 роках асигновано менше 1 млрд. євро ${ }^{16}$ [86]. Для реалізації першого напряму створено окремий виконавчий орган - секретаріат. Для східного напряму передбачено лише посилення штату представництв ЄС у державах-партнерах. Така диспропорція була явно невиправдана. Відчувалася наявність сильного французького лобі для розвитку «Союзу для Середземномор'я», якого бракувало у «Східного партнерства». Зусиль фактично однієї Польщі було недостатньо для забезпечення прориву у співпраці $\mathrm{CC}$ із східноєвропейськими партнерами. Події арабської весни 2010-2011 років, неврегульований палестинсько-ізраїльський конфлікт, війна в Сирії, труднощі демократичних реформ у більшості країн Південного Середземномор'я засвідчили загальну невдачу політики $Є \mathrm{C} \mathrm{y}$ регіоні. Водночас регіон пострадянської Східної Європи і Південного Кавказу цікавив $\mathrm{CC}$ і багатьох його членів насамперед як територія транзиту енергоресурсів, буфер для проникнення в Європу нелегальних мігрантів з Азії.

Утиски політичної опозиції в Україні і Білорусі стримували СС у поглибленні співпраці з їхнім керівництвом. Тому пріоритетними східними партнерами на підписання угоди про асоціацію стали Грузія i Молдова, де при владі утвердилися проєвропейські політичні сили. Російсько-український конфлікт, що розпочався в березні 2014 року і став переконливим свідченням глибокої кризи системи європейської безпеки, засвідчив невдачу політики «Східного партнерства» як наслідок загального політичного прорахунку СС і його провідних держав у відносинах 3 Росією.

Велика Британія не була в когорті ініціаторів «Східного партнерства». Східна Європа не перебувала в центрі уваги першого уряду Д. Кемерона, який проголосив політику відновлення сфери британських інтересів за 
межами Європи. Основна увага офіційного Лондона на найближчій периферії Європи у 2010-2012 роках була зосереджена на регіонах Півночі Африки й Близького Сходу. Про безпеку Східної Європи та ії значимість для системи міжнародних відносин Лондон змушений був згадати лише у зв'язку з революційними подіями в Україні наприкінці 2013 - на початку 2014 року, російською агресією в Криму і на Донбасі.

Британський уряд, незважаючи на традиційну активну підтримку розширення зовнішньополітичного впливу $\mathrm{CC}$ i розвитку відносин із державами Східної Свропи, зайняв помірковану позицію щодо надання перспектив членства країнам «Східного партнерства». У Великій Британії зменшувався ентузіазм щодо розширення СС. Причинами цього стали внутрішні наслідки великомасштабної міграції і побоювання, що приєднання до Свропейського Союзу великих і бідніших держав призведе до негативних соціальних наслідків для самого королівства. Як і більшість інших держав ЄС, Велика Британія виступила за надання перспектив членства східноєвропейським державам у довгостроковій перспективі. Девід Кемерон на саміті Європейської Ради в Брюсселі у грудні 2013 року підтримав укладення Угод про асоціацію СС з Грузією, Молдовою, Вірменією та Україною, незважаючи на відмову керівництва двох останніх підписувати документи. Зрештою 27 червня 2014 року в Брюсселі відбулося підписання асоціації з Грузією, Молдовою та постреволюційною Україною.

Агресія Росії проти України в 2014 році розпочала черговий етап напруги у британсько-російських відносинах. Зміна влади в Києві наприкінці лютого 2014 року й наступне зближення України з СС і США було сприйняте керівництвом Росії як «геополітична катастрофа» ${ }^{17}$. Ідея створення «Великої Свропи» від Атлантики до Уралу, яку свого часу проголошував Ш. де Голль, а на рубежі XX - XXI століть іiі адептами були провідні західні аналітики (наприклад, 3. Бжезінський), зазнала краху. Після анексії Криму керівництво Великої Британії вирішило, що Росія повинна заплатити ціну за порушення міжнародного права і підтримало санкції СС проти Росії. У питаннях політики безпеки Лондон надав перевагу НАТО. Британський уряд відіграв важливу роль у переконуванні інших держав СС, зокрема, Німеччини, у необхідності економічного тиску на Росію.

Однією з причин слабкості «Східного партнерства» стала відсутність дієвої військово-політичної компоненти. Заходи економічного заохочення та гуманітарного сприяння розвитку стабільного суспільства і демократії в пострадянських державах Східної Свропи в сучасних умовах системної кризи європейської безпеки є важливими, але недостатніми. Вони повинні бути забезпечені реальними елементами стратегічної кооперації у сфері 
безпеки та оборони, включенням військово-промислових комплексів тих країн, які бажають стати членами $\mathrm{CC}$, до єдиної мережі європейського військового забезпечення. Головною слабкою стороною програми стала відсутність визначеної перспективи членства в ЄС для східноєвропейських держав, які до нього прагнуть.

Такий стан справ опосередковано став наслідком небажання керівництва Великої Британії посісти провідні позиції в ЄС та ізоляціоністської політики консерваторів у Свропі впродовж 2010-2016 років. Східна політика $\mathrm{CC}$ продовжує формуватися через призму взаємин окремих його держав-членів із Росією, залишається периферійною складовою зовнішньополітичного і безпекового виміру ЄС. Бездіяльність різнопланових структур і механізмів безпеки ЄС на сході Європи є наслідком відсутності політичної волі у керівництва держав об'єднання. Союз міг би запропонувати посередницькі функції і миротворчі послуги наявних у нього багатонаціональних поліцейських сил у зоні АТО на Донбасі. Варто розширити програму формування спільних багатосторонніх військових $\mathrm{i}$ поліцейських підрозділів за участі України, Молдови та держав-членів ЄС і НАТО, а не обмежуватися створенням оперативних військових формувань країн НАТО на кордонах Східної Свропи. Це пришвидшило б інтеграцію оборонних структур України у відповідні системи Північноатлантичного Альянсу і Європейського Союзу. Однак лідери об'єднаної Європи, в тому числі Великої Британії, воліють відмежуватися від безпосереднього врегулювання конфлікту із застосуванням силових засобів і сподіватися на підтримку США. Застосування виключно дипломатичних засобів $є$ неефективним і призвело до заморожування конфлікту. СС підтверджує неготовність виступати в ролі повноцінного центра сили у світовій політиці.

Вихід з $Є С$ в умовах посилення напруги по всій контактній дузі Європейської політики сусідства ускладнить можливості співробітництва Великої Британії із державами Східної Свропи на багатосторонньому регіональному рівні, звузивши їх до рівня відносин з НАТО. Незважаючи на не завжди однозначну політику Лондона щодо розвитку відносин $€ \mathrm{C}$ із державами пострадянської Східної Свропи, ті з них, які прагнуть стати повноправними членами СС (Грузія, Молдова і Україна) внаслідок завершення процесу «Brexit» втратять одного з головних прихильників розширення Співтовариства. Без Великої Британії такі держави, як Угорщина, Італія, Австрія, еліти яких відкрито прагнуть повернутися до звичайних відносин із Росією, будуть мати більше впливу на прийняття відповідних рішень в СС. Саме тому прем'єр-міністр Молдови П. Філіп закликав співгромадян, які мешкають на території Великої Британії, проголосувати на референдумі 23 червня 2016 року проти іiї виходу зі складу 
Євросоюзу $^{18}$. Послаблений без Великої Британії Європейський Союз вигідний Росії, яка може розширити свій дестабілізуючий вплив на східних кордонах Європи. Вихід королівства з ЄС може негативно вплинути на євроінтеграційні перспективи пострадянських країн і значно зменшить їх шанси на членство в об’єднанні навіть у довгостроковій перспективі.

Отже, зовнішня політика Великої Британії щодо держав Східної Європи, зокрема, пострадянського простору, розвивалася в контексті загальної політики Заходу й відчувала сильний вплив російського чинника. Стратегічним завданням зовнішньої політики СС у нових геополітичних умовах стало забезпечення стабільності й безпеки на Сході Свропи, просторах колишнього СРСР, насамперед у країнах найближчої периферії Росії, Україні, Білорусі і Молдові. Першість було надано Росії як правонаступниці СРСР, на яку покладалася роль гаранта стабільності в регіоні. Інші держави розглядалися як «буфер» проти російського експансіонізму на захід. Тому їм відводили вагому роль за мінімуму підтримки. Лише нестабільна політична та економічна ситуація в Росії у 1990-х роках зумовила активізацію політики Британії і загалом СС щодо інших пострадянських країн. Рівень розвитку відносин $Є С$ із зазначеними державами (Росія, Україна, Білорусь, Молдова), які в сукупності разом 3 усіма пострадянськими країнами отримали назву «нові незалежні держави», свідчив про другорядність регіону в зовнішній політиці об'єднання та самої Великої Британії. Оскільки головну увагу СС зосередив на питанні розширення на держави ЦСЄ, пострадянські держави опинилися на другому плані його східноєвропейської політики.

Участь Великої Британії в реалізації східноєвропейської політики $€ \mathrm{C}$, що не відзначалася перманентною активністю, була найбільш помітна на початку 2000-х років у зв'язку із запровадженням Свропейської політики сусідства. Західна Європа (в т. ч. керівництво Великої Британії) зайняла пасивну позицію щодо поширення новітньої російської експансії на пострадянському просторі. На цьому фоні британсько-шведська урядова ініціатива про запровадження Європейської політики сусідства 2002 року мала суперечливий характер - вперше сприяла включенню згаданих країн (окрім Росії) до окремого регіонального виміру зовнішньої політики ЄC і передбачала перспективи поглиблених відносин. Охоплення політикою сусідства держав Південного Середземномор'я, Близького Сходу і Східної Свропи засвідчило другорядність відносин ЄС і провідних держав Західної Свропи з пострадянським країнами, окрім Росії як їхнього енергетичного донора. Інтерес держав Західної Європи у відносинах 3 ними зводився до контрольованості міграційних потоків і безпечного середовища на кордонах. 
Посилення напруги у взаєминах Євросоюзу й окремих західних держав (зокрема, Великої Британії) з Росією у другій половині 2000-х років сприяло певній активізації їхньої політики щодо держав пострадянського простору. Зовнішньополітична позиція урядів Великої Британії щодо держав Східної Свропи варіювалася відповідно до потреб досягнення компромісу з партнерами по СС і динаміки відносин з Росією. Однак британські уряди на кінець десятиліття відійшли від провідних позицій у східноєвропейській політиці об'єднання, взяли пасивну участь у програмі «Східне партнерство», віддавши ініціативу ФРН. Спостерігалася недооцінка ролі і значення цього регіону в зовнішній політиці Великої Британії. Лише політична криза в Україні і військова агресія Росії привернули увагу керівництва Великої Британії до проблем пострадянської Східної Свропи.

Східноєвропейська політика $Є С$ продовжувала формуватися крізь призму відносин із Росією і залишалася периферійною складовою його зовнішньої і безпекової політики. Недооцінка загроз безпеці на Сході Європи поряд із загальними проблемами розвитку об'єднання призвели до його нездатності гарантувати безпеку на своїх східних кордонах без підтримки США і НАТО. До таких результатів причетна Велика Британія, уряд якої за умов виходу з СС і втрати впливу в регіоні ЦСЄ зацікавлений у реорієнтації США на проблеми європейської безпеки та активізації діяльності НАТО в Європі. В умовах виходу Великої Британії з ЄС єдиним реальним каналом іiі впливу на міжнародну ситуацію на Сході Свропи стануть механізми НАТО за підтримки США. Завершення процесу «Brexit» призведе до послаблення позицій держав Східної Свропи у їхному прагненні стати повноправними членами Свропейського Союзу.

${ }^{1}$ Тэтчер М. Искусство управления государством. Стратегии для меняющегося мира. Пер. с англ. Москва: Альпина Паблишер, 2003. С. 87.

2 Document $4 \mathrm{a} / 21$. Declaration of the Extraordinary European Political Cooperation Ministerial Meeting on the "Guidelines on the Recognition of New States in Eastern Europe and in the Soviet Union", Brussels, 16 December 1991. European Foreign Policy. Key Documents. Ed. by Ch. Hill, K.E. Smith. London, 2000. p. 282.

3 Лист Посла України у Сполученому Королівстві Великої Британії і Північної Ірландії В. Василенка Міністру закордонних справ України Б. Тарасюку. № 49/26-353 від 25.06.1998 р. Відділ державного архіву МЗС України, ф. 8, оп. 107, спр. № 117, арк. 131-134.

${ }^{4}$ Лист Тимчасово повіреного України у Сполученому Королівстві Великої Британії і Північної Ірландії С. Кириленка II Територіальному управлінню міністерства закордонних справ України Б. Тарасюку. № 2.5.3./1-392О3МІ від 28.03.2000 р. Відділ державного архіву МЗС Украӥни, ф. 8, оп. 107, спр. №167, арк. 116. 
${ }^{5}$ Гудым А. Республика Молдова и Европейский Союз как партнеры. Кишинев: Центр стратегических исследований и реформ, 2002. С. 23.

${ }^{6}$ Шадурский В. Отношения Республики Беларусь и Европейского Союза: внутренний и внешний контекст. Белорусский журнал международного права и международных отношений. 2003. № 1. URL: http://evolutio.info/content/view/611/232 (дата звернення: 04.08.2016).

7 Капитонова Н.К. Великобритания в конце XX - начале XXI века: от консерваторов к лейбористам. Москва: МГИМО(У) МИД России, 2003. С. 27.

${ }^{8}$ Transcript of the press conference with Prime Minister Tony Blair and President Vladimir Putin. 22 December 2001. URL: http://www.inyourarea.gov.uk/output/ Page1679.asp (дата звернення: 12.06.2015).

9 Трещенков Е.Ю. От восточных соседей к восточным партнерам. Республика Беларусь, Республика Молдова и Украина в фокусе политики соседства Европейского Союза (2002-2012). Санкт-Петербург: Свое издательство, 2013. С. 49.

${ }^{10}$ Castle S. Straw looks to EU's future frontiers. The Independent. 2002. April 16.

${ }^{11}$ A Secure Europe in a better world. European Security Strategy. Brussels, 12 December 2003. pp. 4-8.

${ }^{12}$ Communication from the Commission to the Council and the European Parliament on strengthening the European Neighbourhood Policy. Brussels, 4.12.2006. COM(2006)726 final. pp. 3-4.

${ }^{13}$ Poland, Ukraine and the Baltics. Nervous neighbours. The Economist. 2008. Aug 21.

${ }^{14}$ Bagehot. Lost in the Caucasus. The Economist. 2008. Aug 21.

15 Судак I.I. Особливості реалізації зовнішньополітичного курсу Великобританії. Проблеми міжнародних відносин. 2013. Вип. 6. С. 209.

${ }^{16}$ Communication from the Commission to the European Parliament and the Council "Eastern Partnership". Brussels, 3.12.2008. COM (2008) 823 final (SEC(2008) 2974). URL: http://eur-lex.europa.eu/legal-content/EN/ALL/?uri= CELEX:52008D C0823 (дата звернення: 12.08.2019).

${ }^{17}$ Гринберг Р. Украинский кризис как следствие противоборства пагубного триумфализма и синдрома «старшего брата». Европейская безопасность: события, оиенки, прогнозы. 2014. Выпуск 33 (49). С. 2-3.

${ }^{18}$ Молдова бачить Британію у складі СС. Укрінформ. 21.06.2016. URL: http://www. ukrinform.ua/rubric-abroad/2037498-moldova-bacit-britaniu-u-skladi-es.html (дата звернення: 08.08.2019).

\section{REFERENCES}

1. A Secure Europe in a better world. European Security Strategy. Brussels, 12 December 2003 [in English].

2. Bagehot. Lost in the Caucasus (2008). The Economist, Aug 21 [in English].

3. Castle, S. (2002). Straw looks to EUs future frontiers. The Independent, April 16 [in English].

4. Communication from the Commission to the Council and the European Parliament on strengthening the European Neighbourhood Policy. Brussels, 4.12.2006, COM(2006)726 final, 3-4. [in English].

5. Communication from the Commission to the European Parliament and the Council Eastern Partnership. Brussels, 3.12.2008, COM (2008) 823 final (SEC(2008) 2974). Retrieved from http://eur-lex.europa.eu/legal-content/EN/ALL/?uri=CELEX:52008D C0823 [in English]. 
6. Document 4a/21 (2000). Declaration of the Extraordinary European Political Cooperation Ministerial Meeting on the Guidelines on the Recognition of New States in Eastern Europe and in the Soviet Union, Brussels, 16 December 1991. European Foreign Policy. Key Documents. Ch. Hill, K.E. Smith. (Ed.). London, 282 [in English].

7. Hrynberh, R. (2014). Ukraynskyi kryzys kak sledstvye protyvoborstva pahubnoho tryumfalyzma i syndroma starsheho brata. Evropeiskaia bezopasnost: sobutyia, otsenky, prohnozu, 33 (49), 2-3 [in Russian].

8. Hudym, A. (2002). Respublyka Moldova y Evropeiskyi Sojuz kak partneru. Kyshynev: Tsentr stratehycheskykh issledovanyi i reform [in Russian].

9. Kapytonova, N.K. (2003). Velykobrytanyia v kontse XX - nachale XXI veka: ot konservatorov k leiborystam. Moskva: MHYMO(U) MYD Rossii [in Russian].

10. Moldova bachyt Brytaniiu u skladi YeS. Ukrinform, 21.06.2016. Retrieved from http://www.ukrinform.ua/rubric-abroad/2037498-moldova-bacit-britaniu-u-skladi-es.html [in Ukrainian].

11. Poland, Ukraine and the Baltics. Nervous neighbours (2008). The Economist, Aug 21 [in English].

12. Shadurskyi, V. (2003). Otnoshenyia Respublyky Belarus i Evropeiskoho Sojuza: vnutrennyi s vneshnyi kontekst. Belorusskyi zhurnal mezhdunarodnoho prava $i$ mezhdunarodnukh otnoshenyi, 1. Retrieved from http://evolutio.info/content/view/611/232 [in Russian].

13. Sudak, I.I. (2013). Osoblyvosti realizatsii zovnishnopolitychnoho kursu Velykobrytanii. Problemy mizhnarodnykh vidnosyn, 6, 209 [in Ukrainian].

14. Thatcher, M. (2003). Iskusstvo upravlenyia hosudarstvom. Stratehyy dlia meniaiushchehosia myra. Moskva: Alpyna Pablysher [in Russian].

15. Transcript of the press conference with Prime Minister Tony Blair and President Vladimir Putin. 22 December 2001. Retrieved from http:/www.inyourarea.gov.uk/output/ Page1679.asp [in English].

16. Treshchenkov, E.Yu. (2013). Ot vostochnukh sosedei $k$ vostochnum partneram. Respublyka Belarus, Respublyka Moldova i Ukrayna v fokuse polytyky sosedstva Evropeiskoho Sojuza (2002-2012). Sankt-Peterburh: Svoe izdatelstvo [in Russian]. 